\title{
Hallazgo de plaquetopenia en estudio por hematuria
}

\author{
P. Serrano Frago, M. Allué López, C. Sancho Serrano, Ma ${ }^{a}$.J. Gil Sanz, Á. Borque Fernando, \\ M. Blas Marín, L.A. Rioja Sanz
}

Servicio de Urología Hospital Universitario Miguel Servet. Zaragoza

Actas Urol Esp 2005; 29 (7): 720

$\mathrm{V}$ arón de 61 años sin enfermedades de interés comienza estudio urológico por macrohematuria monosintomática y autolimitada, destacando de sus analíticas la presencia de plaquetopenia de $21.000 / \mathrm{ml}$. En la ecografia abdominal se pone de manifiesto una masa heterogénea renal compatible con hipernefroma y presencia de trombo en vena cava inferior. En el TAC abdominal realizado se confirma la presencia de un hipernefroma con trombo tumoral en cava hasta zona supradiafragmática (Fig.1). Para la valoración de la extensión del trombo se realiza reso- nancia nuclear magnética en la que se evidencia la presencia del trombo hasta ventrículo derecho ocupándolo en su práctica totalidad (Fig. 2). La evolución clínica fue desfavorable evolucionando hacia una coagulopatía por consumo de factores de la coagulación a nivel del trombo y tendencia a la diátesis hemorrágica.

Dra. P. Serrano Frago

Lapuyade, 19 - $1^{\text {o }}$

50007 Zaragoza

E-mail: pserranof@comz.org
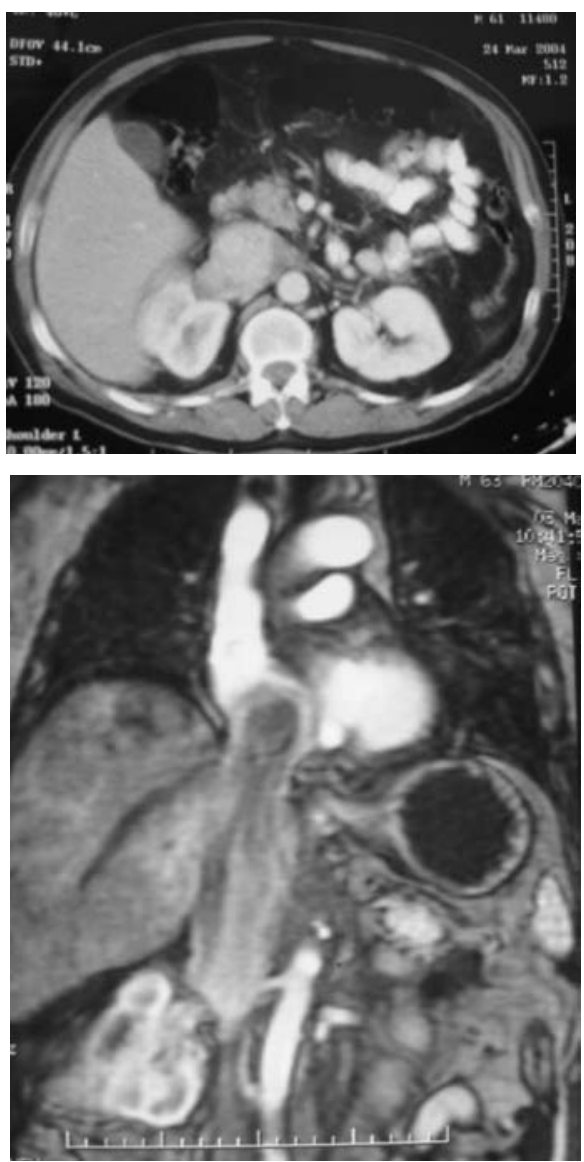
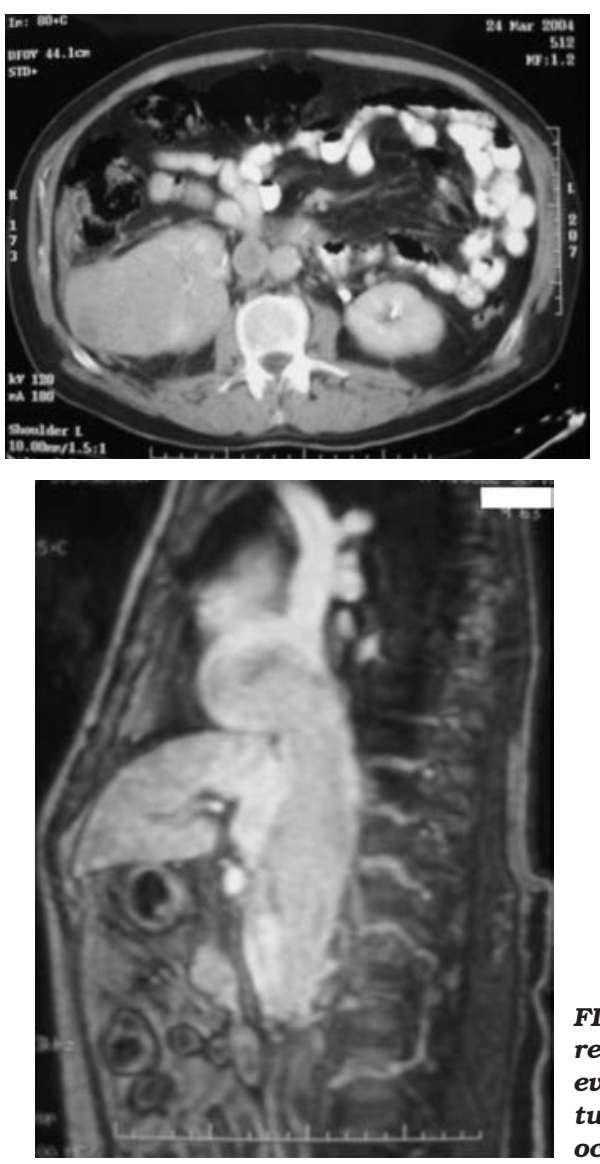

FIGURA 1. TAC abdomino-pélvico evidenciando masa renal heterogénea con captación irregular de contraste y con ocupación de la vena renal $y$ cava inferior.

FIGURA 2. Imágenes sagitales de resonancia nuclear magnética. Se evidencia la presencia de trombo tumoral hasta ventriculo derecho ocupando su totalidad. 